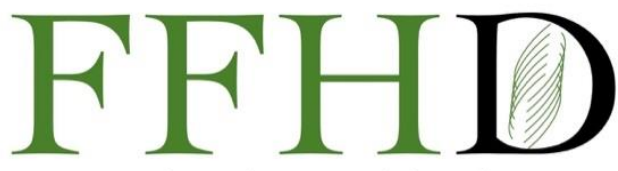

Functional Foods in Health and Disease

\title{
Screening of the antimicrobial activity of some extracts of edible wild plants in Morocco
}

\section{Abdelghani Aboukhalaf ${ }^{1}$, Belkassem El Amraoui ${ }^{1,2}$, Manal Tabatou1 ${ }^{1}$, João Miguel Ferreira da Rocha ${ }^{3}$ and Rekia Belahsen ${ }^{1}$}

\begin{abstract}
${ }^{1}$ Department of Biology, Laboratory of Biotechnology, Biochemistry and Nutrition. Training and Researchy Unit on Nutrition and Food Sciences. Chouaib Doukkali University. School of Sciences, El Jadida, Morocco; ${ }^{2}$ Department of Biology, Biotechnology, Materials and Environment Laboratory, Faculty Polydisciplinary of Taroudant, Ibn Zohr University, Agadir, Morocco; ${ }^{3}$ Department of Biology, Center of Molecular and Environmental Biology, University of Minho, Portugal
\end{abstract}

Corresponding author: Rekia Belahsen, PhD, Professor, Department of Biology, Laboratory of Biotechnology, Biochemistry and Nutrition. Training and Researchy Unit on Nutrition and Food Sciences. Chouaib Doukkali University. School of Sciences, El Jadida, Morocco

Submission Date: May 27 $7^{\text {th }}$ 2020; Acceptance Date: June $17^{\text {th }}, 2020$; Publication Date: June $25^{\text {th }}, 2020$

Please cite this article as: Aboukhalaf A., Belkassem El Amraoui B.E., Tabatou M., Rocha JMFand Belahsen R. Screening of the antimicrobial activity of some extracts of edible wild plants in Morocco. Functional Foods in Health and Disease. 2020; 10(6): 265-273. DOI: https:/doi.org/10.31989/ffhd.v10i6.718

\section{ABSTRACT}

Background: Despite the availability of cultivated food crops and processed food, a large part of the Moroccan population, more particularly the populations of rural areas, still depend on the traditional use of wild plants, which constitute an important component of their food system. However, there is a lack of information on these plants and their medicinal and pharmacological properties, this is why our study aims to detect the antimicrobial activity of certain wild edible plants.

Methods: disc diffusion method was used to evaluate the antimicrobial activities of extracts of Mercurialis annua L, Papaver rhoeas L, Foeniculum vulgare Mill, Chenopodium mural L, and Scolymus hispanicus L against the bacterial species Staphylococcus aureus, Enterococcus faecalis, Escherichia coli, Pseudomonassp, and against the yeasts Cryptococcus neoformans, and Candida albicans

Results: The results showed that the crudeextracts from all the plants studied showed more or less important antimicrobial activities on one or other of the pathogenic microorganisms tested, except for the extract of $M$. 
annua, which showed no activity against all microbial strains. The highest antibacterial activity was observed for Scolymus hispanicus L extract against Escherichia coli (diameter of the inhibition zone: $\varnothing=9 \mathrm{~mm}$ ), the highest antifungal activity was marked for Foeniculum vulgare Mill extract against Candida albicans $(\varnothing=8 \mathrm{~mm})$, and the extract of Scolymus hispanicus L against Cryptococcus neoformans $(\varnothing=8 \mathrm{~mm})$.

Conclusion: These results reveal that, in addition to the role they play in the diet, the food plants studied have an additional biological value due to their bioactive compounds.

Keywords: In vitro antibacterial activity; Antifungal activity; Food wild plants; crude extract, Morocco

CFFC 2020. This is an Open Access article distributed under the terms of the Creative Commons Attribution 4.0 License (http://creativecommons.org/licenses/by/4.0).

INTRODUCTION: Wild plants are neither cultivated nor managed [1]. They are often associated with periods of famine or food shortages. They have contributed to biodiversity, and their consumption makes it possible to combat malnutrition and diversify food thanks to their traditional knowledge by local populations. However, these non-cultivated plants have not received much attention due to the abundance of other foods and changes in eating habits [2, 3]. Moreover, the lack of information on their nutritional content and their potential to serve as safe food means that they are underutilized, and their virtues are not valued.[4].The nutritional properties of wild plants have been reported in several studies[5-9], and in several countries : in Turkey[5], India[6], Greece[10],Ethiopia[11], Bangladesh[12], Morocco[13]and Spain [14].In Morocco, wild food plants had several uses but were neglected by the scientific community, which focused its research on medicinal plants. Therefore, few articles have studied pharmacological activities, including the antimicrobial activity that these food plants may have.

This study aims to fill this gap by assessing the antimicrobial activity of five wild food plants commonly consumed by the local community in the
Sidi Bennour region of Morocco, which are: Mercurialis annua L, Papaver rhoeas L, Foeniculum vulgareMill, Chenopodium mural $\mathrm{L}$ and Scolymus hispanicus $\mathrm{L}$, against bacterial species: Staphylococcus aureus, Enterococcus faecalis, Escherichia coli,Pseudomonas sp, and yeasts Cryptococcus neoformans, and Candida albicans.

\section{MATERIAL AND METHODS:}

Plant material: The plants used for the tests were collected in the Sidi Bennour region (central Morocco) in April 2019.the taxonomic identification of plants was carried out. The food plants, local names, family, and part used in this study were grouped in Table 1.

Bioassay of extracts: After collection, the fresh plant material was dried in an oven at $37^{\circ} \mathrm{C}$, and the powder material was then weighed. A mass of $100 \mathrm{~g}$ of powder is soaked for 48 hours in a mixture of two solvents, a polar solvent (ethanol) and an apolar solvent (dichloromethane) with a proportion of $50 \%$ : $50 \%$. The mixture was then filtered using Whatman filter paper, and the filtrate was concentrated under reduced pressure (at $68^{\circ} \mathrm{C}$ ) using a rotary evaporator until the solvent was removed entirely and the crude extract dried. The extracts were stored at $4^{\circ} \mathrm{C}$ until testing for antimicrobial activities. 
Table 2: Name, family, part used and mode of consumption of the wild food plants studied

\begin{tabular}{|c|c|c|c|c|}
\hline $\begin{array}{l}\text { Scientific } \\
\text { name }\end{array}$ & Family & Local name & $\begin{array}{l}\text { Used } \\
\text { part }\end{array}$ & Consumption mode \\
\hline $\begin{array}{l}\text { Mercurialis } \\
\text { annua } \mathrm{L}\end{array}$ & Euphorbiacées & Horrigalmalssa & $\begin{array}{l}\text { Aerial } \\
\text { parts }\end{array}$ & $\begin{array}{l}\text { The aerial parts of the plant are used for the preparation of } \\
\text { traditional dishes, or they are used as a garnish for soups. [15] }\end{array}$ \\
\hline $\begin{array}{l}\text { Papaver } \\
\text { rhoeas L }\end{array}$ & Papaveraceae & Belaaman & $\begin{array}{l}\text { Leaves } \\
\text { and } \\
\text { flowers }\end{array}$ & $\begin{array}{l}\text { The leaves of this plant are used to prepare traditional dishes, } \\
\text { the flowers are used as spices or as garnish for traditional bread } \\
{[15,16]}\end{array}$ \\
\hline $\begin{array}{l}\text { Foeniculum } \\
\text { vulgareMill }\end{array}$ & Apiaceae & Besbasbeldi & Arial & $\begin{array}{l}\text { The leaves and stems are used as vegetables to prepare } \\
\text { traditional dishes or to be eaten raw, the roots are used as } \\
\text { spices and the seeds are used as condiments. }[15,16]\end{array}$ \\
\hline $\begin{array}{l}\text { Chenopodium } \\
\text { mural L }\end{array}$ & Chenopodiaceae & Berremram & $\begin{array}{l}\text { Aerial } \\
\text { parts }\end{array}$ & $\begin{array}{l}\text { The aerial parts of the plant are used for the preparation of } \\
\text { traditional dishes, or they are used as spices. [15] }\end{array}$ \\
\hline $\begin{array}{l}\text { Scolymus } \\
\text { hispanicus L }\end{array}$ & Astéracées & El guernina & $\begin{array}{l}\text { Stem } \\
\text { and } \\
\text { leaves }\end{array}$ & $\begin{array}{l}\text { The stems are eaten raw, the leaves are cooked as a traditional } \\
\text { vegetable, and the roots are used as spices or garnish of } \\
\text { traditional dishes as they can be eaten raw. }[15,16]\end{array}$ \\
\hline
\end{tabular}

Test strains: Six microbial species have been used, four of which are bacteria, and two are yeasts obtained from the Institute Pasteur Paris Collection (CIP) and the ATCC (American Type Culture Collection (ATCC). The species of the microbial strains are two Gram-negative bacteria: Escherichia coli CIP54127, and Pseudomonas sp, two Gram-positive bacteria: Enterococcus faecalis ATCC19433 and Staphylococcus aureus CIP 209 (ATCC 25923) and two yeasts: Candida albicans 48.72, and Cryptococcus neoformans CIP 960.

These microorganisms have been chosen being considered as pathogenic microorganisms that cause several infections and diseases in different beings, including humans. Among the infections caused by these microorganisms we quote: hospital-acquired pneumonia and meningitis caused by $S$. aureus[17], Hemolytic uremic syndrome caused by E.coli[18], endocarditis caused by E. faecalis[19], urinary tract infections caused by Pseudomonas sp[20], blood stream infections caused by C. albicans[21] and cryptococcosis caused by C. neoformans[22].

Antibacterial activity: A bacterialsuspension $\left(10^{6}\right.$ cells. $\mathrm{ml}^{-1}$ ), was prepared from 24-hour culture on Mueller-Hinton ( $\mathrm{MH})$. The screening for antibacterial activities was carried out by using the paper disc method as previously described by[23, 24]. $20 \mu$ of crude extract was added to a sterile paper disc (diameter: $6 \mathrm{~mm}$ ) placed on a nutrient agar plate containing a bacterium. After 3 hours at $4^{\circ} \mathrm{C}$, the Petri dishes were incubated at $37^{\circ} \mathrm{C}$ for 24 hours at 72 hours. The antibacterial activity of each extract was evaluated by measuring the diameters of the inhibition zones around the discs. Each test was carried out in three copies

Antifungal activity: The disc diffusion method was used for the determination of antifungal activity of the plant extracts[23, 24]. The inoculum of yeast was prepared to give a concentration of $10^{4}$ cells. $\mathrm{ml}^{-1}$, 
from 24-hour culture on Sabouraud dextrose agar (SDA). The inoculated plates were kept at $4^{\circ} \mathrm{C}$ for $3 \mathrm{~h}$ and incubated at $28^{\circ} \mathrm{C}$ for 24 at 72 hours. $20 \mu \mathrm{l}$ of crude extract was added to a sterile paper disc (diameter: $6 \mathrm{~mm}$ ) placed on a nutrient agar plate containing a yeast. The antifungal activity of each extract was evaluated by measuring the diameters of the inhibition zones around the discs. Each test was carried out in three copies.

Ampicillin $(30 \mu \mathrm{g})$ was used as positive control for the tested bacteria and Fluconazole $(30 \mu \mathrm{g})$ for yeast. The same solvents (ethanol- dichloromethane) were used as a negative control for both types of strains.

RESULTS: The antimicrobial test results are presented in Table 2. The data reported in this table correspond to the inhibition diameter of each test strains pathogen. As can be seen, except M. annua, all the plant extracts studied exhibited varying degrees of antimicrobial activity against any of the microorganisms tested. The inhibition zone of the tested bacteria is $4 \mathrm{~mm}$ to $9 \mathrm{~mm}$ without counting the diameter of the disc $(6 \mathrm{~mm})$.

Table 2. In vitro screening of antimicrobial activity of crude extracts from wild food plants.

\begin{tabular}{|c|c|c|c|c|c|c|}
\hline \multicolumn{7}{|c|}{ Diameters of the zones of inhibition ( $\mathrm{mm}$ ) } \\
\hline \multirow{3}{*}{$\begin{array}{l}\text { Microorganisms } \\
\text { Extracts }\end{array}$} & \multicolumn{4}{|l|}{ Bacteria } & \multirow{2}{*}{\multicolumn{2}{|c|}{ Yeasts }} \\
\hline & \multicolumn{2}{|c|}{ Gram-positive bacteria } & \multicolumn{2}{|c|}{ Gram-negativebacteria } & & \\
\hline & S. aureus & E. faecalis & E. coli & Pseudomonas sp & C. neoformans & C. albicans \\
\hline Mercurialis annua & $\mathrm{NI}$ & $\mathrm{NI}$ & $\mathrm{NI}$ & $\mathrm{NI}$ & $\mathrm{NI}$ & $\mathrm{NI}$ \\
\hline Papaver rhoeas & $8 \pm 2,00$ & $6 \pm 2,08$ & $6 \pm 2,51$ & $4 \pm 1,52$ & $\mathrm{NI}$ & $6 \pm 0,3$ \\
\hline Foeniculum vulgare & $8 \pm 0,57$ & $6 \pm 0,55$ & $8 \pm 0,7$ & $\mathrm{NI}$ & $\mathrm{NI}$ & $8 \pm 0,15$ \\
\hline Chenopodium mural & $\mathrm{NI}$ & $5 \pm 1,52$ & $5 \pm 2,42$ & $\mathrm{NI}$ & $\mathrm{NI}$ & $\mathrm{NI}$ \\
\hline Scolymus hispanicus & $\mathrm{NI}$ & $8 \pm 1,52$ & $9 \pm 0,00$ & $\mathrm{NI}$ & $8 \pm 1,52$ & $\mathrm{NI}$ \\
\hline Ampicillin & 16 & 17 & 16 & 15 & & \\
\hline Fluconazole & & & & & 20 & 18 \\
\hline
\end{tabular}

NI: No inhibition

According to Ali et al (Ali et al., 2001), the crude extracts tested have good antimicrobial activity when the inhibition zone is $8 \mathrm{~mm}$ or more; moderate antimicrobial activity if it is of $6-7 \mathrm{~mm}$; low antimicrobial activity if the zone is $4-5 \mathrm{~mm}$; very low antimicrobial activity if it is $2-3 \mathrm{~mm}$, or without antimicrobial activity

As can be seen, except $M$. annua, all the plant extracts studied exhibited varying degrees of antimicrobial activity against any of the microorganisms tested. The inhibition zone of the tested bacteria is $4 \mathrm{~mm}$ to $9 \mathrm{~mm}$ without counting the diameter of the disc $(6 \mathrm{~mm})$.

According to the results of Table 2, the $M$. annua crude extract showed no antibacterial activity against all strains. $P$. rhoeas extract has inhibited all bacterial strains, with good antibacterial activity against $S$. aureus, moderate antimicrobial activity against $E$. coli, and $E$. faecalis, and low antibacterial activity against Pseudomonas sp. The F.vulgare extract showed good antibacterial activity against the strains $S$. aureus and $E$. coli, moderate activity against $E$. faecalis, and zero 
antibacterial activity against Pseudomonas sp. The extract of C.mural showed no antibacterial activity against the strains $S$. aureus and Pseudomonas $S p$, but it showed low antibacterial activity against $E$. faecalis and $E$. coli. Finally, the extract of S.hispanicus has good antibacterial activity against $E$. coli and $E$. faecalis; in contrast, it has no effect on S. aureus and Pseudomonas sp. Regarding antifungal activity, most of the extracts showed no antifungal activity against $C$. neoformans and C.albicans strains except for $P$. rhoeas extract which showed moderate antifungal activity against $C$. albicans, the extract of F.vulgare which showed good antifungal activity against the strain $C$. albicans and finally the extract of S. hispanicus which showed good antifungal activity against $C$.neoformans.

Table 2 also shows that the crude extracts tested in this study exhibit antimicrobial activities, which are low compared to the standard antibiotics used. However, these activities remain considerable as crude extracts, and not their pure compounds are used.

DISCUSSION: The data found in this study reveal that $M$. annuaextract has no antimicrobial activity against all strains tested. This finding is consistent with previous studies that reported none antimicrobial activity of the extract of this species against S.aureus, Pseudomonas aeruginosa, Propionibacteriumacne, and C.albicans[25]. This result is also confirmed by other studies that report that M.annua extract does not affect several strains, including S.aureus and E.coli tested in this study [26, 27]Our results are also consistent with the literature regarding the antimicrobial activity of $P$. rhoeas extract against all microbial strains tested except $C$. neoformans. Indeed, many publications that have documented the antibacterial activity of $P$.rhoeas report the same effects of its extract against various microbial strains, namely S. aureus, $E$. coli, Pseudomo-nas aeruginosa and C. albicans [2831]. Other research on di-ethyl ether, chloroform, and P.rhoeas acetone extracts also revealed antibacterial activity against S.aureus[32]. Also, Coban et al. showed a positive association of antimicrobial activity of P.rhoeas extracts with the alkaloid composition of these extracts and mainly with a major alkaloid, roemerin, which has an aporphine alkaloid skeleton and a methylenedioxy fragment[29].

The low antibacterial activity was showed by the C. murale crude extract against $E$. coli and $E$. faecalis strains against $E$. coli and $E$. faecalis strains. These results are inconsistent with the work of Ali et al. They found that ethanolic extracts prepared from C. murale sheets showed no antibacterial activity against the strains $E$. faecalis, E.coli and Pseudomonas aeruginosa [33]. This difference between our results and those of the literature can be explained by the choice of solvents, the extraction method, the collection region and by collection period of plants. Besides, the absence of activity of C.murale extract on S. aureus is consistent with the results of other studies showing that the extract alone from the leaves of this plant showed no antibacterial activity against this strain[34]. Our study also reported antimicrobial activity of the species F.vulgare. The latter is considered as an important medicinal and aromatic plant well known and widely used as carminative, digestive, lactagogue, and diuretic and in the treatment of respiratory and gastrointestinal disorders. Its seeds are used as flavorings in bakery products, meat and fish dishes, ice cream, alcoholic beverages, and herbal blends [35]. The extract of this species shows excellent activity against food-borne pathogens $E$. 
coli and S. aureus. This result is similar to those found by Kaur and Arora, which showed that the aqueous and organic extracts of F.vulgare seeds had effects against E.faecalisstrains, S.aureus, E. coli, P.aeruginosa, Salmonella typhimurium,

Shigellaflexneri and Salmonella Typhi [36]. In another study, F. vulgare fruit extract was shown to have an antibacterial effect against other germs, including Campylobacter jejuni and Helicobacter pylori [37].Seed extracts from $F$. vulgare also have antifungal activity against $C$. albicans [38].Several chemical constituents of $F$. vulgare have been identified as active antimicrobial principles. Among these, a derivative of phenylpropanoid - Dillapional has proven to be the active antimicrobial principle in the stem of $F$. vulgare. Another molecule Scopoletin, derived from coumarin, was also isolated from this plant with a marginal antimicrobial effect[39].

S. hispanicus is a plant included in herbal remedies [40].The leaves, stems, and flowers are traditionally used as a "bitter" tonic to stimulate appetite, improve bile secretion, reduce flatulence, and facilitate digestion[41].It has also historically been used as a diuretic, diaphoretic, and antipyretic[41].The plant extract showed good antibacterial activity against $E$. faecalis, E. coli, and $C$. neoformans. Other recent studies have reported numerous antimicrobial activities for $S$. hispanicus against several strains, namely E.coli, Bacillus aureus, Listeria monocytegenes, Salmonella typhimurium, Aspergillus fumigatus, Aspergillus ochraceus, Penicilliumitalicum, and Penicilliumcyclopium[42]. Marmouzietal. found very strong antibacterial activity from the roots of $S$. hispanicus against E. coli. Moreover, the flowers of this plant were also reported to be very active against $S$. aureus and Bacillus subtilis. Other research has also shown better leaf activity of $S$. hispanicus against Salmonella enterica and $P$. aeruginosa strains. [4].The antimicrobial properties of this species could be attributed to its chemical composition. Indeed, the different parts of the plant have high levels of $\alpha$-tocopherol, flavonoids, and phenolic acids that have been associated with the control of foodborne pathogens $[4,43]$.

CONCLUSION: In addition to their use as food, edible wild plants studied in this work, except $M$. annua, exhibit significant antimicrobial activities that can be attributed to their phytochemical composition. Two of these plants, Foeniculum vulgare Mill and Scolymus hispanicus $\mathrm{L}$ present important activities both antibacterial and antifungal. Exploration of these potentially valuable sources is of great importance to the local population and the pharmaceutical industry.

As a perspective, fractionation and isolation of the bioactive compounds responsible for the significant antimicrobial activities of certain extracts such as F.vulgare and S.hispanicus are recommended. In addition, the development of methods of cultivation and preservation of these promising plants is essential.

Acknowledgments: We want to thank A. Belahyan, Professor at the Faculty of Science of El Jadida, for his assistance in the scientific identification of the species used and Y. Lahlou, member of our laboratory «LBBN» for technical assistance

This work benefited from an endowment of the Moroccan Ministry of National Education and Scientific Research for Chouaib Doukkali University laboratories.

Abbreviations: Institute Pasteur Paris Collection (CIP), American Type Culture Collection (ATCC), 
Mueller-Hinton (MH), Sabouraud dextrose agar (SDA).

Competing interests: The authors declare that they have no financial interest or conflicts of interest.

Author's contributions: All authors contributed to this work. A. Aboukhalaf implemented the research

\section{REFERENCES}

1. Sõukand R, Kalle R: What Is Wild Food Plant. In. Changes in the Use of Wild Food Plants in Estonia. Switzerland: Springer; 2016: 5-11.

2. Grivetti LE, Ogle BM: Value of traditional foods in meeting macro-and micronutrient needs: the wild plant connection. Nutr Res $\quad$ Rev 2000, 13:31-46. https://doi.org/10.1079/095442200108728990

3. Luczaj L, Pieroni A, Tardío J, Pardo-de-Santayana M, Sõukand R, Svanberg I, Kalle R: Wild food plant use in 21 st century Europe, the disapperance of old traditions and the search for new ciusines involving wild edibles. Acta Soc Bot Pol 2012, 81. http://dx.doi.org/10.5586/asbp.2012.031

4. Marmouzi I, El Karbane M, El Hamdani M, Kharbach M, NaceiriMrabti H, Alami R, Dahraoui S, El Jemli M, Ouzzif Z, Cherrah Y: Phytochemical and pharmacological variability in Golden Thistle functional parts: comparative study of roots, stems, leaves and flowers. Nat Prod Res 2017, 31:26692674. https://doi.org/10.1080/14786419.2017.1283494

5. Kibar B, Kibar H: Determination of the nutritional and seed properties of some wild edible plants consumed as vegetable in the Middle Black Sea Region of Turkey. S Afr J Bot2017,

$108: 117-125$ https://doi.org/10.1016/j.sajb.2016.10.011

6. Datta S, Sinha B, Bhattacharjee S, Seal T: Nutritional composition, mineral content, antioxidant activity and quantitative estimation of water soluble vitamins and phenolics by RP-HPLC in some lesser used wild edible plants. Heliyon2019, 5:e01431. and drafted the paper. B. El Amraoui and M. Tbatou participated to the design of the experimental protocol. J. M. Ferreira da Rocha participated to the results discussion and the paper editing. R. Belahsen supervised the research, contributed to the results discussion and to the paper writing.

7. Rana ZH, Alam MK, Akhtaruzzaman M: Nutritional Composition, Total Phenolic Content, Antioxidant and $\alpha$ Amylase Inhibitory Activities of Different Fractions of Selected Wild Edible Plants.Antioxidants 2019, 8:203. https://doi.org/10.3390/antiox8070203

8. Sánchez-Mata PG-HaMdC: The Contribution of Wild Plants to Dietary Intakes of Micronutrients (II): Mineral Elements. In. Mediterranean Wild Edible Plants Ethnobotany and Food Composition Tables. Edited by María de Cortes SánchezMata JT. New York: Springer; 2016: 141-172. 10.1007/9781-4939-3329-7_7

9. María de Cortes Sánchez-Mata MCM-G, Morales aP: The Contribution of Wild Plants to Dietary Intakes of Micronutrients (I): Vitamins. In. Mediterranean Wild Edible Plants Ethnobotany and Food Composition Tables. Edited by María de Cortes Sánchez-Mata JT. New York: Springer; 2016: 111-140. 10.1007/978-14939-3329-7_6

10. Zeghichi S, Kallithraka S, Simopoulos AP, Kypriotakis Z: Nutritional composition of selected wild plants in the diet of Crete. World Rev Nutr Diet 2003, 91:22-40.

11. Getachew GA, Asfaw Z, Singh V, Woldu Z, Baidu-Forson JJ, Bhattacharya S: Dietary values of wild and semi-wild edible plants in Southern Ethiopia. Afr J Food AgricNutr Dev2013, 13.

12. Alam MK, Rana ZH, Islam SN, Akhtaruzzaman M: Comparative assessment of nutritional composition, polyphenol profile, antidiabetic and antioxidative properties of selected edible wild plant species of Bangladesh. Food 
Chem

2020:126646

https://doi.org/10.1016/j.foodchem.2020.126646

13. Tbatou M, Kabil M, Belahyan A, Belahsen R: Dietary potential of some forgotten wild leafy vegetables from Morocco.Int Food Res J2018, 25:1829-1836.

14. Morales $P$, Fernández-Ruiz V, Sánchez-Mata $M$, Cámara $M$, Tardío J: Optimization and application of FL-HPLC for folates analysis in 20 species of mediterranean wild vegetables. Food Anal methods2015, 8:302-311. https://doi.org/10.1007/s12161-014-9887-6

15. Tbatou M, Belahyan A, Belahsen R: 3. Wild edible plants traditionally used in the country side of ElJadida, coastal area in the center of Morocco by Manal Tbatou1, Abdelmonaim Belahyan2, Rekia Belahsen1. Life scileafl $2016,75: 28$ to $48-28$ to 48

16. Nassif F, Tanji A: 3. Gathered food plants in Morocco the long-forgotten species in ethnobotanical research by Fatima Nassifand AbbesTanji. Life scileafl 2013, 37:17 to $54-17$ to 54.

17. Lowy F: Staphylococcus aureus infections. N. Engl. J. Med. 1998.

18. Griffin PM, Tauxe RV: The epidemiology of infections caused by Escherichia coli 0157 : H7, other enterohemorrhagic $\mathrm{E}$. coli, and the associated hemolytic uremic syndrome. Epidemiol Rev1991, 13:60-98.

19. Thurlow LR, Thomas VC, Narayanan S, Olson S, Fleming SD, Hancock LE: Gelatinase contributes to the pathogenesis of endocarditis caused by Enterococcus faecalis. Infect Immun2010, https://doi.org/10.1128/iai.01118-09

20. Mittal R, Aggarwal S, Sharma S, Chhibber S, Harjai K: Urinary tract infections caused by Pseudomonas aeruginosa: a minireview. J Infect Public Heal 2009, 2:101-111. https://doi.org/10.1016/j.jiph.2009.08.003

21. Mavor A, Thewes S, Hube B: Systemic fungal infections caused by Candida species: epidemiology, infection process and virulence attributes. Curr drug targets2005, 6:863-874. https://doi.org/10.2174/138945005774912735
22. Chayakulkeeree M, Perfect JR: Cryptococcosis. In. Diagnosis and treatment of human mycoses. Edited by Hospenthal DR, Rinaldi MG. Totowa, New Jersey: Springer; 2008: 255-276.

23. Bauer A: Antibiotic susceptibility testing by a standardized single disc method. Am J clinpathol1966, 45:149-158.

24. Eloff JN: Avoiding pitfalls in determining antimicrobial activity of plant extracts and publishing the results.BMC ComplemAltern $\quad M \quad 2019, \quad$ 19:1-8. https://doi.org/10.1186/s12906-019-2519-3

25. Assaf AM, Haddadin RN, Aldouri NA, Alabbassi R, Mashallah S, Mohammad M, Bustanji Y: Anti-cancer, anti-inflammatory and anti-microbial activities of plant extracts used against hematological tumors in traditional medicine of Jordan. J Ethnopharmacol 2013, 145:728-736. https://doi.org/10.1016/j.jep.2012.11.039

26. Yildirim $A B$, Karakas FP, Turker AU: In vitro antibacterial and antitumor activities of some medicinal plant extracts, growing in Turkey.Asian Pac J Trop Med. 2013, 6:616-624. https://doi.org/10.1016/\$1995-7645(13)60106-6

27. Al-Mariri A, Safi M: In vitro antibacterial activity of several plant extracts and oils against some gram-negative bacteria.Iran. J Med Sci 2014, 39:36.

28. Kostic DA, Mitic SS, Mitic MN, Zarubica AR, Velickovic JM, Dordevic AS, Randelovic SS: Phenolic contents, antioxidant and antimicrobial activity of Papaver rhoeas L. extracts from Southeast Serbia.J Med Plant Res 2010, 4:1727-1732. https://doi.org/10.5897/JMPR10.121

29. Çoban I, Toplan GG, Özbek B, Gürer ÇU, Sarıyar G: Variation of alkaloid contents and antimicrobial activities of Papaver rhoeas L. growing in Turkey and northernCyprus.Pharm biol2017, 55:1894-1898. https://doi.org/10.1080/13880209.2017.1340964

30. Çoban EP, Biyik H, Törün B, Yaman F: Evaluation the antimicrobial effects of Pistaciaterebinthus L. and Papaver rhoeas L. extracts against some pathogen microorganisms. Indian J Pharm Educ2017, 51:377-380. 10.5530/ijper.51.3s.51 
31. Ghizlane H, Aziz B: Pharmacological properties of some medicinal plants, its components and using fields. In. Fruits, Vegetables, and Herbs. Edited by Watson RR, Preedy VR. Elsevier; 2016: 41-56. http://dx.doi.org/10.1016/B978-0$12-802972-5.00003-2$

32. Ünsal Ç, Özbek B, Sarıyar G, Mat A: Antimicrobial activity of four annual Papaver species growing in Turkey.Pharm biol2009,

$47: 4-6$ https://doi.org/10.1080/13880200802392468

33. Ali NA, Jülich W-D, Kusnick C, Lindequist U: Screening of Yemeni medicinal plants for antibacterial and cytotoxic activities.J Ethnopharmacol2001， 74:173-179. https://doi.org/10.1016/S0378-8741(00)00364-0

34. Abdel-Aziz MS, Shaheen MS, El-Nekeety AA, Abdel-Wahhab MA: Antioxidant and antibacterial activity of silver nanoparticles biosynthesized using Chenopodium murale leaf extract. J Saudi ChemSoc 2014, 18:356-363. https://doi.org/10.1016/j.jscs.2013.09.011

35. Rather MA, Dar BA, Sofi SN, Bhat BA, Qurishi MA: Foeniculum vulgare: A comprehensive review of its traditional use, phytochemistry, pharmacology, and safety.

Arab J Chem2016, 9:S1574-S1583. https://doi.org/10.1016/j.arabjc.2012.04.011

36. Kaur GJ, Arora DS: Antibacterial and phytochemical screening of Anethumgraveolens, Foeniculum vulgare and Trachyspermumammi. BMC ComplemAltern M2009, 9:30. https://doi.org/10.1186/1472-6882-9-30

37. Mahady GB, Pendland SL, Stoia A, Hamill FA, Fabricant D, Dietz BM, Chadwick LR: In vitro susceptibility of Helicobacter pylori to botanical extracts used traditionally for the treatment of gastrointestinal disorders. Phytother Res 2005, 19:988-991. https://doi.org/10.1002/ptr.1776

38. Pai MB, Prashant G, Murlikrishna K,Shivakumar K, Chandu G: Antifungal efficacy of Punicagranatum, Acacia nilotica, Cuminumcyminum and Foeniculum vulgare on Candida albicans: an in vitro study. Indian J Dent Res 2010, 21:334. $\underline{10.4103 / 0970-9290.7079}$

39. Kwon YS, Choi WG, Kim WJ, Kyung cKim W, Kim MJ, Kang WH, Kim CM: Antimicrobial constituents of Foeniculum vulgare.Arch Pharm Res2002, 25:154-157. https://doi.org/10.1007/BF02976556

40. Ugurlu E, Secmen O: Medicinal plants popularly used in the villages of Yunt Mountain (Manisa-Turkey). Fitoterapia2008, 79:126-131. https://doi.org/10.1016/j.fitote.2007.07.016

41. Altiner DD, Sahan Y: A Functional Food Additive: Scolymus Hispanicus L. Flour. Int J Food Eng2016, 2. 10.18178/ijfe.2.2.124-127

42. Petropoulos SA, Fernandes Â, Tzortzakis N, Sokovic M, Ciric A, Barros L, Ferreira IC: Bioactive compounds content and antimicrobial activities of wild edible Asteraceae species of the Mediterranean flora under commercial cultivation conditions. Food Res Int2019, 119:859-868. https://doi.org/10.1016/j.foodres.2018.10.069

43. Kenny O, Smyth T, Walsh D, Kelleher $C$, Hewage $C$, Brunton $\mathrm{N}$ : Investigating the potential of under-utilised plants from the Asteraceae family as a source of natural antimicrobial and antioxidant extracts.Food Chem2014, 161:79-86. https://doi.org/10.1016/j.foodchem.2014.03.126 